\title{
Control of Scaphoideus titanus with Natural Products in Organic Vineyards
}

\author{
Federico Tacoli ${ }^{1, *}$, Nicola Mori ${ }^{2}$, Alberto Pozzebon ${ }^{2}$ (D), Elena Cargnus ${ }^{1}$, Sarah Da Vià ${ }^{2}$, \\ Pietro Zandigiacomo ${ }^{1}$, Carlo Duso ${ }^{2}$ and Francesco Pavan ${ }^{1}$ \\ 1 Department of Agricultural, Food, Environmental and Animal Sciences, University of Udine, \\ via delle Scienze 206, Udine 33100, Italy; elena.cargnus@uniud.it (E.C.); pietro.zandigiacomo@uniud.it (P.Z.); \\ francesco.pavan@uniud.it (F.P.) \\ 2 Department of Agronomy, Food, Natural Resources, Animals and Environment (DAFNAE), \\ University of Padova, via dell'Università 16, Agripolis, Legnaro 35020, Padova, Italy; \\ nicola.mori@unipd.it (N.M.); alberto.pozzebon@unipd.it (A.P.); sarah.davia@hotmail.com (S.D.V.); \\ carlo.duso@unipd.it (C.D.) \\ * Correspondence: tacoli.federico@spes.uniud.it; Tel.: +39-0432-558508; Fax: +39-0432-558501
}

Received: 13 November 2017; Accepted: 13 December 2017; Published: 16 December 2017

\begin{abstract}
The leafhopper Scaphoideus titanus is the vector of 'Candidatus Phytoplasma vitis', the causal agent of Flavescence dorée (FD) a key disease for European viticulture. In organic vineyards, the control of S. titanus relies mostly on the use of pyrethrins that have suboptimal efficacy. During 2016, three field trials were conducted to evaluate the efficacy of kaolin, orange oil, insecticidal soap and spinosad against $S$. titanus nymphs, in comparison with pyrethrins. The activity of kaolin was evaluated also in the laboratory. In all field trials, kaolin had an efficacy against nymphs comparable to pyrethrins, while the other products were not effective. Laboratory results confirmed that kaolin increased nymph mortality. In organic vineyards, kaolin and pyrethrins are valuable tools in the management of FD. Nevertheless, their efficacy is lower compared to that of the synthetic insecticides used in conventional viticulture. Therefore, further research should be conducted in order to identify alternatives to synthetic insecticides for $S$. titanus control in the context of organic viticulture.
\end{abstract}

Keywords: flavescence dorée; Scaphoideus titanus; vector control; natural substances; kaolin; pyrethrins; organic viticulture

\section{Introduction}

The leafhopper Scaphoideus titanus Ball (Hemiptera: Cicadellidae) is the vector of 'Candidatus Phytoplasma vitis', the causal agent of Flavescence dorée (FD), which is a Grapevine Yellows Disease (GYD) that causes severe damage in European vineyards [1-4].

Flavescence-dorée phytoplasma is a quarantine disease in the European and Mediterranean Plant Protection Organization (EPPO) region [5] and control measures are mandatory in some European countries [6]. The FD control strategy in vineyards relies mostly on S. titanus control and on the roguing of symptomatic grapevines, from which the vector can acquire the phytoplasma [6-9]. However, since insecticide applications are poorly effective against infected adults migrating into vineyards [10-12], the strategy adopted is effective only if external sources of infected individuals (i.e., infected vineyards, both abandoned or cultivated but untreated against S. titanus, and wild American grapevines growing in hedgerows and groves) are previously removed.

In Italian conventional vineyards, one to two insecticide applications against $S$. titanus can keep the populations of this vector and the percentage of FD-symptomatic grapevines at acceptable levels $[11,13,14]$. Infected grapevines can also die or recover, but this latter capability varies across cultivars. In cultivars with a high incidence of recovery, the chemical control of $S$. titanus can bring the 
percentage of symptomatic grapevines back to acceptable levels without their roguing [15]. The high efficacy of insecticide applications in vineyards is due to the biology of S. titanus: (i) it is monophagous on Vitis sp. plants, therefore external sources can be easily removed, and (ii) it completes only one generation a year after being overwintered as eggs $[6,16,17]$. The control strategy aims to kill nymphs at the completion of the latency period, that is, before they have reached the fourth-fifth instars, which is the point that they become infective $[13,18]$. The need for more than one insecticide application derives from the prolonged egg-hatching period, which lasts for over 45 days [17]. The timing of insecticide applications is usually based on nymph samplings. In Italy, the first insecticide application is performed at the appearance of third instar nymphs and the second application occurs after two or three weeks to kill the nymphs hatched after the first application [13].

In conventional vineyards, an effective control of $S$. titanus nymphs is ensured by the use of organophosphates, pyrethroids and neonicotinoids [19-23]. All these insecticides are characterized by a long residual activity.

In organic vineyards, the control of $S$. titanus is difficult and often higher population levels are observed as compared to conventional vineyards, despite several insecticide applications [11]. The most effective insecticides in organic viticulture are pyrethrins, which are used alone or in combination with piperonyil butoxide, mineral oil or sesame oil [21,22,24-29]. However, the effectiveness of pyrethrins is lower than synthetic insecticides [11,22], because the former exert a marked knock-down effect when nymphs are directly hit, but the effectiveness declines to low levels when nymphs are kept in contact with fresh residues [26]. The absence of residual activity in pyrethrins mandates many applications to cover the entire egg-hatching period adequately. Mineral oil, spinosad, azadirachtin and Beauveria bassiana are considered less effective than pyrethrins or totally ineffective [22,24-28]. The need for repeated pyrethrin applications to overcome the low persistence of this class of insecticides may result in detrimental effects on predatory mites of the Phytoseiidae family [26,28,30]. Considering both the low efficacy and the toxicity to non-target organisms of pyrethrins, the identification of other natural products is necessary.

Recently, natural products such as kaolin, essential oils and insecticidal soap (i.e., potassium salts of fatty acids) have been found to be effective against leafhoppers or other Hemiptera [31-35]. In particular, a high efficacy of kaolin against the leafhoppers Empoasca vitis (Göthe) and Zygina rhamni Ferrari (Hemiptera: Cicadellidae) was observed both in vineyards and in the laboratory [32]. In the laboratory, plant essential oils have been found to exhibit a toxic activity against mealybugs (Hemiptera: Pseudococcidae) [33]. Insecticidal soap was effective in the control of some Pentatomidae under field conditions [34] and Halyomorpha halys (Stål) (Hemiptera: Pentatomidae) in the laboratory [35]. In the present study, the efficacy of kaolin, orange oil, insecticidal soap and spinosad against S. titanus nymphs was compared to pyrethrins in field trials. To evaluate if kaolin had any effects on egg laying by females, nymph population levels in the kaolin and control were assessed in the year following the kaolin applications. The activity of kaolin on nymphs was also evaluated in the laboratory.

\section{Materials and Methods}

\subsection{Field Trials}

In 2016, three field trials were carried out in vineyards located in north-eastern Italy to evaluate the efficacy of five natural products (Table 1) against $S$. titanus in comparison to an untreated control. Vineyard I (Togliano, Udine district, $46^{\circ} 06^{\prime} 45^{\prime \prime} \mathrm{N}, 13^{\circ} 24^{\prime} 40^{\prime \prime} \mathrm{E}, 140 \mathrm{~m}$ a.s.l., cultivar Merlot) is a 15 -yr-old conventional vineyard with grapevines growing under the Guyot training system with distances between and along the rows of $2.4 \mathrm{~m}$ and $0.7 \mathrm{~m}$, respectively. Vineyard II (Nimis, Udine district, $46^{\circ} 11^{\prime} 34^{\prime \prime} \mathrm{N}, 13^{\circ} 15^{\prime} 42^{\prime \prime}$ E, $200 \mathrm{~m}$ a.s.l., cultivar Verduzzo Friulano) is a 15-yr-old conventional vineyard with grapevines growing under the Guyot training system with distances between and along the rows of $2.9 \mathrm{~m}$ and $0.8 \mathrm{~m}$, respectively. Vineyard III (Lonigo, Vicenza district, $45^{\circ} 24^{\prime} 04^{\prime \prime} \mathrm{N}, 11^{\circ} 23^{\prime} 26^{\prime \prime} \mathrm{E}$, $31 \mathrm{~m}$ a.s.1., cultivar Garganega) is a 20-yr-old organic vineyard with grapevines growing under the 
"Pergola" training system with distances between and along the rows of $4.0 \mathrm{~m}$ and $1.0 \mathrm{~m}$, respectively. In all vineyards, a standard fungicide program was followed and no insecticides were applied during the growing season.

Table 1. Natural products tested in the vineyards against Scaphoideus titanus.

\begin{tabular}{|c|c|c|c|c|}
\hline \multirow{2}{*}{ Active Constituent } & \multicolumn{2}{|c|}{ Commercial Product } & \multirow{2}{*}{$\begin{array}{c}\text { Application Rate } \\
\text { in Water }\end{array}$} & \multirow{2}{*}{$\begin{array}{l}\text { Application } \\
\text { Timing * }\end{array}$} \\
\hline & Name & Formulation & & \\
\hline Kaolin & $\begin{array}{c}\text { Surround WP } \\
\text { (Tessenderlo Kerley Inc., } \\
\text { Phoenix, Arizona, USA) }\end{array}$ & $\begin{array}{l}\text { WP (wettable powder), } \\
\text { 95\% kaolin }\end{array}$ & $2 \% w / v$ & $A, B, C$ \\
\hline Orange oil & $\begin{array}{l}\text { Prev-Am Plus (Nufarm } \\
\text { Italia, Milano, Italy) }\end{array}$ & $\begin{array}{l}\text { SL (soluble liquid), } \\
5.88 \% \text { orange oil }\end{array}$ & $0.5 \% v / v$ & C, D \\
\hline Insecticidal soap & $\begin{array}{l}\text { Flipper (Dow } \\
\text { Agrosciences Italia, } \\
\text { Milano, Italy) }\end{array}$ & $\begin{array}{c}\text { SL (soluble liquid) } \\
47.8 \% \text { potassium salts of } \\
\text { fatty acids }\end{array}$ & $2 \% v / v$ & C, D \\
\hline Spinosad & $\begin{array}{l}\text { Laser (Dow } \\
\text { Agrosciences Italia, } \\
\text { Milano, Italy) }\end{array}$ & $\begin{array}{c}\text { SC (suspension } \\
\text { concentrate), } 44.2 \% \text { pure } \\
\text { spinosad }\end{array}$ & $0.02 \% v / v$ & C, D \\
\hline Pyrethrins & $\begin{array}{l}\text { Biopiren Plus (Copyr, } \\
\text { Milano, Italy) }\end{array}$ & $\begin{array}{c}\text { EC (emulsifiable } \\
\text { concentrate), } 2 \% \text { pure } \\
\text { pyrethrins }\end{array}$ & $0.16 \% v / v$ & C, D \\
\hline
\end{tabular}

$\left(^{*}\right)$ A, B, C, D refer to the appearance of first-instar, second-instar, third-instar and fourth-instar nymphs of S. titanus, respectively.

In all trials, a randomized block design with four replicates was adopted. Each block (row) was divided into 6 plots of 20 (vineyard I) or 16 (vineyard II) or 15 (vineyard III) grapevines and product applications were planned as described in Table 1. The timing of the applications was based on the appearance of different $S$. titanus instar nymphs, in particular: (A) first-instar nymphs (26 May in vineyard I, 25 May in vineyard II and 26 May in vineyard III); (B) second-instar nymphs (1 June in vineyard I, 3 June in vineyard II and 1 June in vineyard III); (C) third-instar nymphs (8 June in vineyard I, 8 June in vineyard II and 10 June in vineyard III); and (D) fourth-instar nymphs (14 June in vineyard I, 14 June in vineyard II and 15 June in vineyard III). All products were applied using a backpack sprayer (M1200, Cifarelli s.p.a., Voghera, PV, Italy) at a rate of 1000 L/ha spraying the canopy and the suckers growing along the vertical trunk.

In all vineyards, S. titanus nymphs were sampled before application timing A (25 May in vineyard I, 3 June in vineyard II and 26 of May in vineyard III) and weekly up to one week after application timing D (i.e., 28 June in vineyard I, 6 July in vineyard II and 30 June in vineyard III). Sampling was conducted on the 10 central grapevines of each plot. Scaphoideus titanus nymphs were counted on sucker leaves. Suckers were chosen as sampling units because in spring they host the highest nymph density $[13,36]$. In vineyards I and II, five sucker leaves per grapevine were sampled for a total of 200 leaves per treatment. In vineyard III, all leaves of 10 suckers per plot were sampled for a total of 40 suckers per treatment being the population density too low to use leaf as sampling unit.

In vineyards I and II, S. titanus nymphs were also sampled in early June of 2017 in the plots that in 2016 belonged to the control and the kaolin. In vineyard III, this sampling was not done because a late frost heavily damaged suckers.

\subsection{Laboratory Bioassay}

A laboratory bioassay was carried out to evaluate the efficacy of kaolin against $S$. titanus nymphs. Mortality of first-instar and second-instar nymphs was compared in two treatments: (i) nymphs placed on kaolin-treated leaves (kaolin); and (ii) nymphs placed on water-treated leaves (control). The sample size was equal to 50 leaves per treatment. For this purpose, 100 insecticide-free grapevine leaves were 
collected from vineyard I. In the laboratory, each leaf was visually checked to ensure the absence of S. titanus individuals. Fifty leaves were sprayed with kaolin and 50 with water, and each were inserted individually into transparent self-sealing plastic bags $(20 \times 33 \mathrm{~cm})$. The kaolin application was done at a $4 \% \mathrm{~W}: \mathrm{V}$ (Surround WP:water) concentration with a hand sprayer to run-off. The S. titanus nymphs used in the bioassay were collected from insecticide-free leaves picked in the same vineyard. First- and second-instar nymphs were randomly chosen on these leaves and a single individual was induced to move onto each bagged leaf with a brush. After 1, 2, 3, 6 and 9 days from the beginning of the bioassay, the bags were checked to note whether nymphs were alive or dead.

\subsection{Statistical Analyses}

Statistical analyses were performed with Microsoft Excel 2013 for Windows (Microsoft Corporation 2013, Redmond, WA, USA) and SAS (v 9.4, SAS Institute, Cary, NC, USA).

Data collected in the field trials in 2016 were analyzed using mixed linear models performed with the PROC MIXED (SAS Institute 9.4). In modelling treatment, time and their interactions were considered as sources of variation and $F$ tests were used to evaluate their effects $(\alpha=0.05)$. Numbers of $S$. titanus nymphs were considered as response variable with repeated measures made at different times, i.e. sampling dates. Treatments were compared using a $t$-test to the least-square means with Bonferroni adjustment of the $p$-values $(\alpha=0.05)$. Data collected in the spring of 2017 were compared with a $t$-test. Data were $\log (x+1)$ transformed prior to the analyses.

Data collected in the laboratory bioassay were compared with a Fisher's exact test and the mortality percentage of nymphs was calculated following Abbott [37].

\section{Results}

\subsection{Field Trials}

Vineyard I. During the sampling period, significant differences were recorded among treatments $\left(F_{5,19.7}=9.52, p<0.0001\right)$ (Figure 1$)$. Considering the overall trial period, only kaolin and pyrethrins significantly reduced $S$. titanus nymph densities compared to the control. The time effect was significant $\left(F_{5,74.2}=167.51, p<0.0001\right)$ because $S$. titanus numbers were low at the beginning of the trial, increased until the fourth sampling date and were very low on the last sampling date. A significant interaction time*treatment was found $\left(F_{25,76.5}=7.22, p<0.0001\right)$ because the efficacy of the treatments varied over time. In the pyrethrin-treated plots, population densities dropped to low numbers after the first application (timing C), but on the subsequent sampling dates they rose to levels similar to the other treatments, despite a second application (timing D). Kaolin-treated plots showed nymph densities lower than the control on the three sampling dates after the first application (timing A), but not on the last sampling date.

In the spring of 2017, no significant difference in nymph populations was observed between the plots treated with kaolin in the previous year and the control (mean \pm SD nymphs per leaf, $1.12 \pm 0.41$ vs. $1.48 \pm 0.18)\left(t_{6}=1.59, p=0.16\right)$.

Vineyard II. During the sampling period, significant differences were recorded among treatments $\left(F_{5,36.4}=6.13, p=0.0003\right)$ (Figure 2$)$. Considering the overall trial period, only kaolin significantly reduced $S$. titanus nymph densities compared to the control. The time effect was significant $\left(F_{5,83.1}=37.9, p<0.0001\right)$ because $S$. titanus numbers were low at the beginning of the trial, increased until the fourth sampling date and were very low on the last sampling date. The time * treatment interaction was not significant $\left(F_{25,84.9}=0.85, p=0.67\right)$.

In the spring of 2017, no significant difference in nymph populations was observed between the plots treated with kaolin in the previous year and the control (mean \pm SD nymphs per leaf, $0.20 \pm 0.04$ vs. $0.18 \pm 0.10)\left(t_{6}=0.72, p=0.50\right)$.

Vineyard III. During the sampling period significant differences were recorded among treatments $\left(F_{5,40.1}=4.29, p=0.0032\right)$ (Figure 3). Considering the overall trial period, only kaolin and pyrethrins 
significantly reduced $S$. titanus nymph densities compared to the control. The time effect was significant $\left(F_{5,86.1}=34.34, p<0.0001\right)$ because $S$. titanus numbers were low at the beginning of the trial, increased until the second sampling date and were very low on the last sampling date. The time * treatment interaction was not significant $\left(F_{25,87.1}=0.91, p=0.59\right)$.

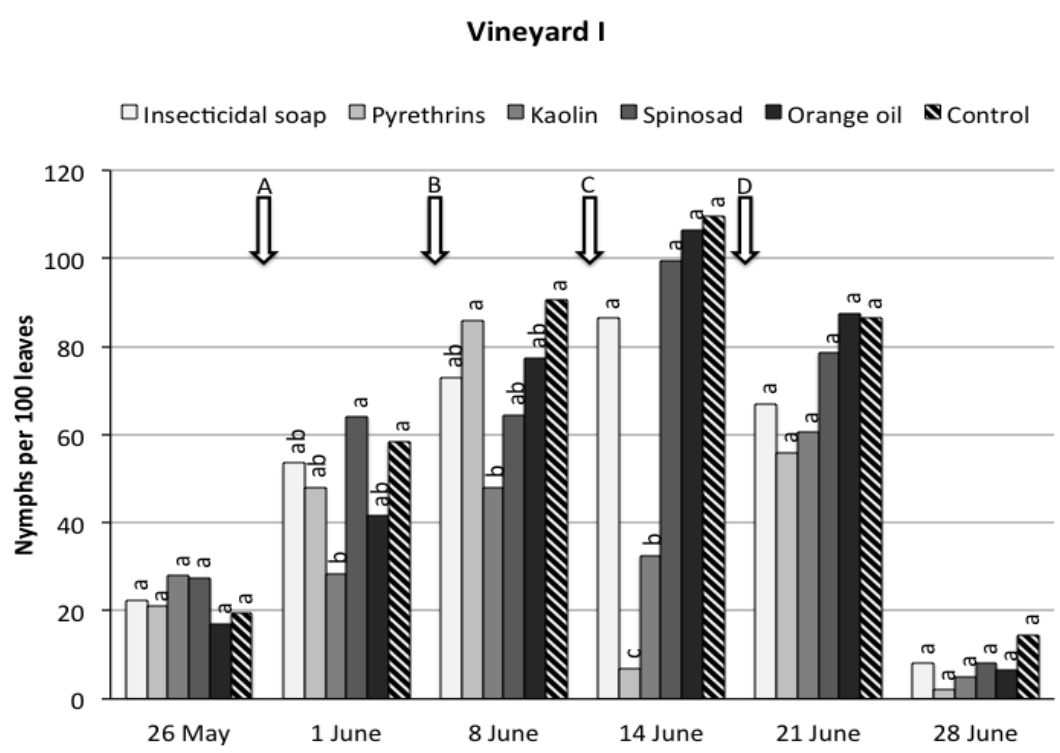

Figure 1. Scaphoideus titanus nymphs recorded on grapevine suckers during the sampling period in vineyard I under six different treatments. Within the same date, different small letters above bars indicate significant differences according to $t$-tests on the least square means with Bonferroni correction $(\alpha=0.05)$. The arrows indicate the application timings of the natural products.

\section{Vineyard II}

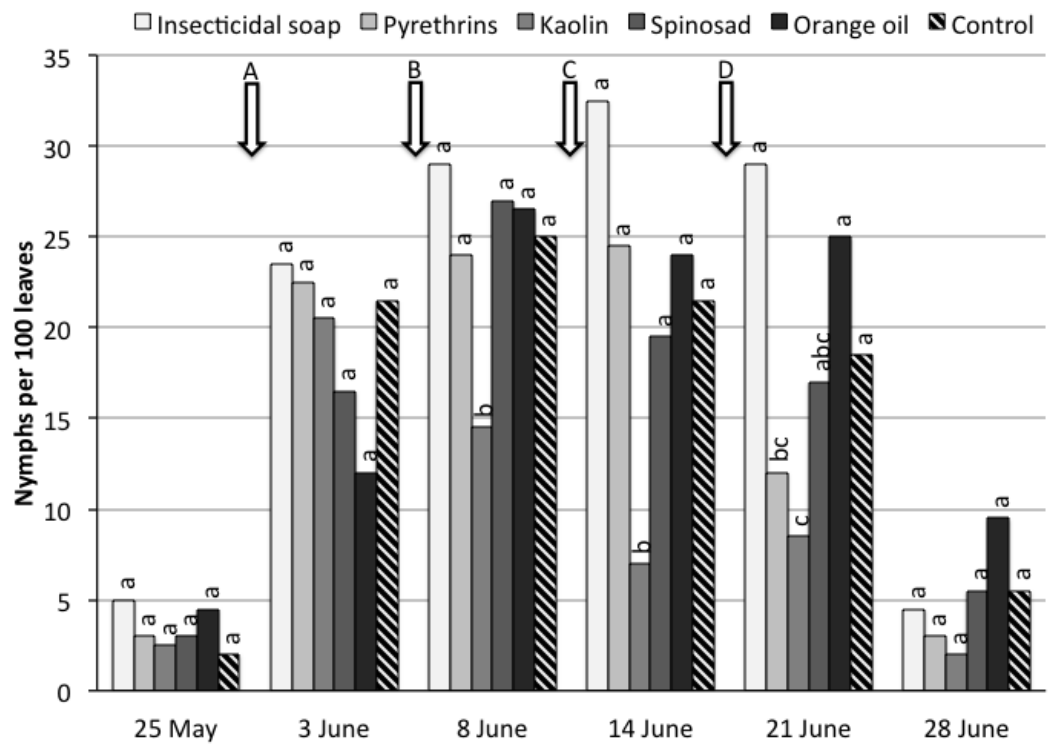

Figure 2. Scaphoideus titanus nymphs recorded on grapevine suckers during the sampling period in vineyard II under six different treatments. Within the same date, different small letters above bars indicate significant differences according to $t$-tests on the least square means with Bonferroni correction $(\alpha=0.05)$. The arrows indicate the application timings of the natural products. 


\section{Vineyard III}

$\square$ Insecticidal soap $\square$ Pyrethrins $\square$ Kaolin $\square$ Spinosad $\square$ Orange oil $\mathbf{\Delta}$ Control

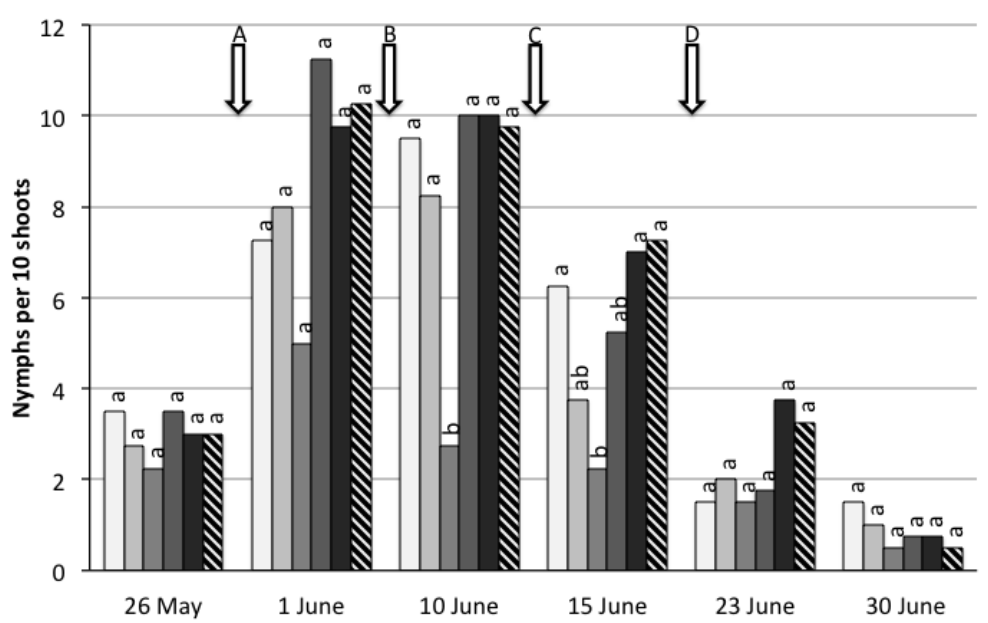

Figure 3. Scaphoideus titanus nymphs recorded on grapevine suckers during the sampling period in vineyard III under six different treatments. Within the same date, different small letters above bars indicate significant differences according to $t$-tests on the least square means with Bonferroni correction $(\alpha=0.05)$. The arrows indicate the application timings of application of the natural products.

\subsection{Laboratory Bioassay}

One day after the beginning of the bioassay, a significantly higher mortality rate of first-instar and second-instar nymphs of $S$. titanus was observed in the kaolin-treated leaves compared to the control (Figure 4). This difference persisted until the end of the bioassay. The Abbott efficacy calculated for kaolin at the end of this experiment was $46 \%$.

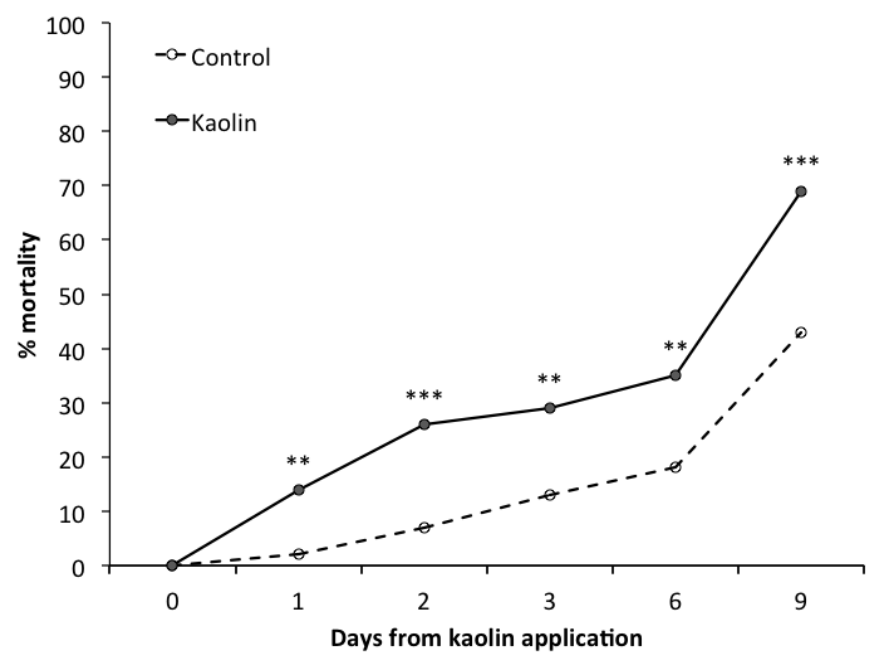

Figure 4. Scaphoideus titanus nymph mortality recorded in the laboratory in the kaolin and control. ${ }^{\prime * * \prime}$ and ${ }^{* * * * \prime}$ indicate significant differences for $\alpha=0.01$ and $\alpha=0.001$, respectively, according to Fisher's exact test.

\section{Discussion and Conclusions}

Among the natural products tested in the current study, only kaolin showed an efficacy comparable to that of pyrethrins in the control of $S$. titanus nymphs in vineyards. Based on laboratory data, kaolin increased the mortality of $S$. titanus nymphs. A previous laboratory study showed that 
kaolin applications increase the mortality of the nymphs of the grapevine leafhopper E. vitis [32]. Because kaolin acted against $E$. vitis as a feeding inhibitor, a similar mode of action might be involved with the $S$. titanus nymphs. However, the Abbott mortality of first-instar and second-instar nymphs feeding on kaolin-treated leaves for three days was much lower for S. titanus (43.2\% in this study) than for E. vitis (96.4\% in [32]). The lower susceptibility of S. titanus can be explained with its larger body size because also for E. vitis a lower mortality ( $48.8 \%$ at the third day) occurred when older and then larger nymphs were tested [32]. Moreover, based on nymph samplings carried out in the year following the kaolin applications, the plants coated with this product did not appear to have had any oviposition-deterrent effect.

In all field trials, three kaolin applications against $S$. titanus had an efficacy comparable to two pyrethrin applications (considered as standard procedure in organic Italian vineyards). In these trials, kaolin and pyrethrins reduced nymph numbers with a suboptimal efficacy. Neither of the natural products had significant efficacy in late June when egg hatching was almost complete, and when the aged nymphs disperse along the growing suckers and are able to colonize the upper parts of the grapevine canopy.

In organic vineyards, a kaolin-based control strategy against $S$. titanus should be preferred to a pyrethrin-based one, particularly when the effects on other pests are considered. Indeed, unlike pyrethrins, kaolin showed a high efficacy against E. vitis and Z. rhamni [32] and a moderate effect against $L$. botrana both in the laboratory [38] and in the field (Tacoli et al., unpublished data) [39]. Kaolin also has some application advantages over pyrethrins, such as greater persistence and an absence of application-timing issues, due to its use as a preventive control measure from the beginning of S. titanus egg hatching. On the other hand, kaolin has been associated with agronomical benefits in vineyards such as reductions in berry-sunburn damage and higher efficiency in water use [40,41]. Nevertheless, side effects of kaolin and pyrethrins on natural enemies should be considered [42,43].

In conventional viticulture, some of the abovementioned benefits of kaolin seem to be less appealing. First of all, the efficacy of kaolin against $S$. titanus is probably much lower than that of synthetic insecticides, as suggested by some studies [23,44]. However, the negative effects of some synthetic insecticides towards natural enemies [45] could counterbalance this gap.

The moderate effect of three kaolin applications on S. titanus suggests that kaolin alone is not enough to achieve the same level of FD control in organic viticulture as obtained with synthetic insecticides in conventional viticulture. Therefore, further research on S. titanus control strategies is needed, and in an Integrated Pest Management (IPM) context, alternatives to chemical control should also be considered, such as: (i) conservation and augmentative biological control [6]; (ii) mating disruption based on vibrational disturbance [46-49]; (iii) symbiotic control based on bacteria that damage the vector or its ability to transmit the phytoplasma causal agent [50,51]; and (iv) push-and-pull strategies [6,52]. Moreover, because S. titanus eggs are laid under the bark of two- or more-year-old wood [36], the following cultural practices can be used to reduce $S$. titanus populations: (i) the removal of two-year-old wood from vineyards after winter pruning; and (ii) the removal of suckers growing along the vertical trunk, which are abundantly colonized by nymphs that hatch from the eggs laid into the bark of the trunk [53,54]. In organic vineyards, the integration of these control tools with kaolin applications could increase the efficacy of $S$. titanus management.

Acknowledgments: This research did not receive any specific grant from funding agencies in the public, commercial or not-for-profit sectors.

Author Contributions: F.T., N.M., A.P., C.D. and F.P. conceived and designed the experiments; F.T., E.C., P.Z. and F.P. performed vineyards I and II field trials and laboratory bioassay; N.M and S.D.V. performed the vineyard III field trial; F.T., A.P. and F.P. analyzed the data; all authors wrote the paper.

Conflicts of Interest: The authors declare no conflict of interest. 


\section{References}

1. Schvester, A.; Carle, P.; Moutous, G. Transmission de la Flavescence dorée de la vigne par Scaphoideus littoralis Ball. (Homopt. Jassidae). Ann. Épiphyt. 1963, 14, 175-198. (In French)

2. Carraro, L.; Loi, N.; Kuszala, C.; Clair, D.; Boudon-Padieu, E.; Refatti, E. On the ability-inability of Scaphoideus titanus Ball to transmit different grapevine yellow agents. Vitis 1994, 33, 231-234.

3. Bianco, P.A.; Alma, A.; Casati, P.; Scattini, G.; Arzone, A. Transmission of $16 \mathrm{SrV}$ phytoplasmas by Scaphoideus titanus Ball in Northern Italy. Plant Protect. Sci. 2001, 37, 49-56.

4. Mori, N.; Bressan, A.; Martini, M.; Guadagnini, M.; Girolami, V.; Bertaccini, A. Experimental transmission by Scaphoideus titanus Ball of two Flavescence dorée-type phytoplasmas. Vitis 2002, 41, 99-102.

5. EPPO/CABI. Quarantine Pests for Europe; CAB International: Wallingford, UK, 1997.

6. Chuche, J.; Thiéry, D. Biology and ecology of the Flavescence dorée vector Scaphoideus titanus: A review. Agron. Sustain. Dev. 2014, 34, 381-403. [CrossRef]

7. Caudwell, A. La flavescence dorée de la vigne en France. Phytoma-La Défense des végétaux 1981, 325, 16-19. (In French)

8. Barba, M. La lotta obbligatoria alla flavescenza dorata e al suo vettore Scaphoideus titanus. In Flavescenza dorata e altri giallumi della vite in Toscana e in Italia; Quaderno ARSIA 2005; Bertaccini, A., Braccini, P., Eds.; ARSIA Regione Toscana: Firenze, Italy, 2005; Volume 3, pp. 135-138. (In Italian)

9. Weintraub, P.G.; Beanland, L. Insect vectors of phytoplasmas. Annu. Rev. Entomol. 2006, 51, 91-111. [CrossRef] [PubMed]

10. Carle, P.; Schvester, D. Nouvelle mise au point su la lutte contre Scaphoideus titanus Ball, cicadelle vectrice de la Flavescence dorée de la vigne. Rev. Zool. Agric. Appl. 1964, 63, 107-114. (In French)

11. Pavan, F.; Mori, N.; Bigot, G.; Zandigiacomo, P. Border effect in spatial distribution of Flavescence dorée affected grapevines and outside source of Scaphoideus titanus vectors. Bull. Insectol. 2012, 65, 281-290.

12. Lessio, F.; Portaluri, A.; Paparella, F.; Alma, A. A mathematical model of flavescence dorée epidemiology. Ecol. Model. 2015, 312, 41-53. [CrossRef]

13. Pavan, F.; Stefanelli, G.; Villani, A.; Mori, N.; Posenato, G.; Bressan, A.; Girolami, V. Controllo della flavescenza dorata attraverso la lotta contro il vettore Scaphoideus titanus Ball. In Flavescenza dorata e altri giallumi della vite in Toscana e in Italia; Quaderno ARSIA 2005; Bertaccini, A., Braccini, P., Eds.; ARSIA Regione Toscana: Firenze, Italy, 2005; Volume 3, pp. 91-108. (In Italian)

14. Bosco, D.; Mori, N. Flavescence dorée vector control in Italy. Phytopathog. Mollicutes 2013, 3, 40-43. [CrossRef]

15. Pavan, F.; Mori, N.; Bressan, S.; Mutton, P. Control strategies for grapevine phytoplasma diseases: Factors influencing the profitability of replacing symptomatic plants. Phytopathol. Mediterr. 2012, 51, 11-22.

16. Schvester, D.; Moutous, G.; Bonfilis, J.; Carle, P. Étude biologique des cicadelles de la vigne dans le sud-ouest de la France. Ann. Épiphyt. 1962, 13, 205-237. (In French)

17. Vidano, C. Scoperta in Italia dello Scaphoideus littoralis Ball cicalina americana collegata alla "Flavescence dorée" della vite. L'Italia Agricola 1964, 101, 1031-1049. (In Italian)

18. Schvester, D.; Carle, P.; Moutous, G. Nouvelles données sur la transmission de la flavescence dorée de la vigne par Scaphoideus littoralis Ball. Ann. Zool. Écol. Anim. 1969, 1, 445-465. (In French)

19. Mori, N.; Posenato, G.; Sancassani, G.; Tosi, L.; Girolami, V. Insetticidi per il controllo delle cicaline nei vigneti. L'Informatore Agrario 1999, 55, 93-97. (In Italian)

20. Posenato, G.; Mori, N.; Bressan, A.; Stefanelli, G.; Pavan, F.; Girolami, V. Valutazione dell'attività di alcuni insetticidi nei confronti degli adulti di Scaphoideus titanus Ball e Metcalfa pruinosa (Say). Atti Giornate Fitopatologiche 2002, 1, 459-462. (In Italian)

21. Mazzoni, E.; Colla, R.; Chiusa, B.; Ciampitti, M.; Cravedi, P. Experiences for vector control of grape golden flavescence in Lombardia and Emilia Romagna (Northern Italy) vineyards. IOBC/WPRS Bull. 2003, 26, 221-225.

22. Jermini, M.; Gusberti, M.; Schaub, L.; Linder, C.; Gugerli, P.; Schärer, S.; Emery, S. Flavescence dorée and Scaphoideus titanus: Distribution and control in Switzerland. IOBC/WPRS Bull. 2008, 36, 107-111.

23. Žežlina, I.; Škvarč, A.; Bohinc, T.; Trdan, S. Testing the efficacy of single applications of five insecticides against Scaphoideus titanus on common grapevines. Int. J. Pest Manag. 2013, 59, 1-9. [CrossRef]

24. Caobelli, R.; Carcereri, G. Lotta biologica alla cicalina della vite. L'Informatore Agrario 1995, 51, 75-77. (In Italian) 
25. Bottura, N.; Mori, N.; Posenato, G.; Sancassani, G.P.; Girolami, V. Lotta alle cicaline nei vigneti a conduzione biologica. L'Informatore Agrario 2003, 59, 75-79. (In Italian)

26. Mori, N.; Bottura, N.; Posenato, G.; Sancassani, G.P.; Girolami, V. Lotta contro Scaphoideus titanus Ball nei vigneti a conduzione biologica. Atti Giornate Fitopatologiche 2004, 1, 111-116. (In Italian)

27. Mori, N.; Tonello, D.; Posenato, G.; Pozzebon, A.; Duso, C. Efficacy of biopesticides against Scaphoides titanus Ball in different experimental conditions. IOBC/WPRS Bull. 2014, 105, 45-48.

28. Gusberti, M.; Jermini, M.; Wyss, E.; Linder, C. Efficacité d'insecticides contre Scaphoideus titanus en vignobles biologiques et effets secondaires. Rev. Suisse Vitic. Arboric. Hortic. 2008, 40, 173-177. (In French)

29. Constant, N. L'utilisation du pyrèthre naturel pour lutter contre la cicadelle de la flavescence dorée en viticulture biologique. Progrès Agricole et Viticole 2009, 126, 334-340. (In French)

30. Duso, C.; Angeli, G.; Castagnoli, M.; Liguori, M.; Facchin, P.; Malagnini, V.; Pozzebon, A. Pesticides and phytoseiid mites: A synopsis of research carried out on grapes, apples and vegetables in northern and central Italy. In Acarology XI: Proceedings of the International Congress; Merida, Mexico, September 8-13, 2002; Morales-Malacara, J.B., Behan-Pelletier, V., Ueckermann, E., Pérez, T.M., Estrada, E., Gispert, C., Badii, M., Eds.; Merida, Instituto de Biololgía, UNAM; Facultad de Ciencias, UNAM; Sociedad Latinoamericana de Acarología: Ciudada Universitaria, Mexico, 2007; pp. 325-337.

31. Tubajika, K.M.; Civerolo, E.L.; Puterka, G.J.; Hashim, J.M.; Luvisi, D.A. The effects of kaolin, harpin, and imidacloprid on development of Pierce's disease in grape. Crop Prot. 2007, 26, 92-99. [CrossRef]

32. Tacoli, F.; Pavan, F.; Cargnus, E.; Tilatti, E.; Pozzebon, A.; Zandigiacomo, P. Efficacy and mode of action of kaolin in the control of Empoasca vitis and Zygina rhamni (Hemiptera: Cicadellidae) in vineyards. J. Econ. Entomol. 2017, 110, 1164-1178. [CrossRef] [PubMed]

33. Karamaouna, F.; Kimbaris, F.; Michaelakis, A.; Papachristos, D.; Polissiou, M.; Papatsakona, P.; Tsora, E. Insecticidal activity of plant essential oils against the vine mealybug, Planococcus ficus. J. Insect Sci. 2013, 13, 142. [CrossRef] [PubMed]

34. Trdan, S.; Žnidarčič, D.; Valič, N. Field efficacy of three insecticides against cabbage stink bugs (Heteroptera: Pentatomidae) on two cultivars of white cabbage. Int. J. Pest Manag. 2006, 52, 79-87. [CrossRef]

35. Lee, D.H.; Short, B.D.; Nielsen, A.L.; Leskey, T.C. Impact of organic insecticides on the survivorship and mobility of Halyomorpha halys (Hemiptera: Pentatomidae) in the laboratory. Florida Entomol. 2014, 97, 414-421. [CrossRef]

36. Bagnoli, B.; Gargani, E. Survey on Scaphoideus titanus egg distribution on grapevines. IOBC/WPRS Bull. 2011, 67, 233-237.

37. Abbott, W.S. A method for computing the effectiveness of an insecticide. J. Econ. Entomol. 1925, 18, $265-267$. [CrossRef]

38. Pease, C.E.; López-Olguín, J.F.; Pérez-Moreno, I.; Marco-Mancebón, V. Effects of kaolin on Lobesia botrana (Lepidoptera: Tortircidae) and its compatibility with the natural enemy, Trichogramma cacoeciae (Hymenoptera: Trichogrammatidae). J. Econ. Entomol. 2016, 109, 740-745. [CrossRef] [PubMed]

39. Tacoli, F.; Cargnus, E.; Kiaeian Moosavi, F.; Zandigiacomo, P.; Pavan, F.; University of Udine, Udine, Italy. Unpublished Data. 2017.

40. Coniberti, A.; Ferrari, V.; Dellacassa, E.; Boido, E.; Carrau, F.; Gepp, V.; Disegna, E. Kaolin over sun-exposed fruit affects berry temperature, must composition and wine sensory attributes of Sauvignon blanc. Eur. J. Agron. 2013, 50, 75-81. [CrossRef]

41. Brillante, L.; Belfiore, N.; Gaiotti, F.; Lovat, L.; Sansone, L.; Poni, S.; Tomasi, S. Comparing kaolin and pinolene to improve sustainable grapevine production during drought. PLoS ONE 2016, 11, e0156631. [CrossRef] [PubMed]

42. Jansen, J.P.; Defrance, T.; Warnier, A.M. Effect of organic-farming-compatible insecticides on four aphid natural enemy species. Pest Manag. Sci. 2010, 66, 650-656. [CrossRef] [PubMed]

43. Pascual, S.; Cobos, G.; Seris, E.; González-Núñez, M. Effects of processed kaolin on pests and non-target arthropods in a Spanish olive grove. J. Pest Sci. 2010, 83, 121-133. [CrossRef]

44. Pavan, F.; Bellomo, C.; Vidoni, F.; Bigot, G.; Ostan, M.; Boccalon, W.; Bressan, S.; Mutton, P.; Frausin, C.; De Biasio, A.C.; et al. Efficacia della lotta insetticida contro Scaphoideus titanus Ball in Friuli Venezia Giulia. Supplemento. Notiziario. ERSA 2005, 17, 11-21. (In Italian)

45. Pozzebon, A.; Tirello, P.; Moret, R.; Pederiva, M.; Duso, C. A fundamental step in IPM on grapevine: Evaluating the side effects of pesticides on predatory mites. Insects 2015, 6, 847-857. [CrossRef] [PubMed] 
46. Mazzoni, V.; Prešern, J.; Lucchi, A.; Virant-Doberlet, M. Reproductive strategy of the Nearctic leafhopper Scaphoideus titanus Ball (Hemiptera: Cicadellidae). Bull. Entomol. Res. 2009, 99, 401-413. [CrossRef] [PubMed]

47. Eriksson, A.; Anfora, G.; Lucchi, A.; Lanzo, F.; Virant-Doberlet, M.; Mazzoni, V. Exploitation of insect vibrational signals reveals a new method of pest management. PLoS ONE 2012, 7, e32954. [CrossRef] [PubMed]

48. Polajnar, J.; Eriksson, A.; Rossi Stacconi, M.V.; Lucchi, A.; Anfora, G.; Virant-Doberlet, M.; Mazzoni, V. The process of pair formation mediated by substrate-borne vibrations in a small insect. Behav. Process. 2014, 107, 68-78. [CrossRef] [PubMed]

49. Polajnar, J.; Eriksson, A.; Virant-Doberlet, M.; Mazzoni, V. Mating disruption of a grapevine pest using mechanical vibrations: From laboratory to the field. J. Pest Sci. 2016, 89, 909-921. [CrossRef]

50. Alma, A.; Daffonchio, D.; Gonella, E.; Raddadi, N. Microbial symbionts of Auchenorrhyncha transmitting phytoplasmas: A resource for symbiotic control of phytoplasmoses. In Phytoplasmas: Genomes, Plant Hosts and Vectors; Weintraub, P.G., Jones, P., Eds.; CABI: Wallingford, UK, 2010; pp. 272-292.

51. Gonella, E.; Crotti, E.; Rizzi, A.; Mandrioli, M.; Favia, G.; Daffonchio, D.; Alma, A. Horizontal transmission of the symbiotic bacterium Asaia sp. in the leafhopper Scaphoideus titanus Ball (Hemiptera: Cicadellidae). BMC Microbiol. 2012, 12 (Suppl. 1), S4. [CrossRef] [PubMed]

52. Mazzoni, V.; Ioriatti, C.; Trona, F.; Lucchi, A.; De Cristofaro, A.; Anfora, G. Study on the role of olfaction in host plant detection of Scaphoideus titanus (Hemiptera: Cicadellidae) nymphs. J. Econ. Entomol. 2009, 102, 974-980. [CrossRef] [PubMed]

53. Cara, C.; Trivellone, V.; Linder, C.; Junkert, J.; Jermini, M. Influence de la gestion des repousses du tronc et du bois de taille sur les densités de Scaphoideus titanus. Rev. Suisse Vitic. Arboric. Hortic. 2013, 45, 114-119. (In French)

54. Trivellone, V.; Jermini, M.; Posenato, G.; Mori, N. Influence of pruning wood management and suckering on Scaphoideus titanus Ball density in two distinct wine-growing area. In Book of Abstracts IOBC-WPRS Meeting of the Working Group on "Integrated Protection and Production in Viticulture"; IOBC-WPRS: Vienna, Austria, 2015; p. 11.

(C) 2017 by the authors. Licensee MDPI, Basel, Switzerland. This article is an open access article distributed under the terms and conditions of the Creative Commons Attribution (CC BY) license (http:/ / creativecommons.org/licenses/by/4.0/). 